\title{
PENGARUH PENAMBAHAN Na-ALGINAT DALAM PROSES EKSFOLIASI GRAFIT DENGAN METODE PENCAMPURAN
}

\section{EFFECT OF Na-ALGINATE ADDITION IN EXFOLIATION PROCESS OF GRAPHITE WITH MIXING METHOD}

\author{
Muhammad Arsyik Kurniawan*, Rohini Pujiarti \\ Program Studi Kimia, Fakultas MIPA, Universitas Islam Indonesia \\ Jalan Kaliurang KM 14,5 Yogyakarta 55584 \\ Email : m.arsyik@gmail.com
}

Received: 2 Februari 2017; Accepted: 23 Maret 2017

\begin{abstract}
Abstrak. Studi pengaruh penambahan Na-alginat dalam proses eksfoliasi grafit telah dilakukan melalui sintesis dan kajian komputasi menggunakan teori fungsi kerapatan pada level B3LYP/6-31G(d). Penelitian ini bertujuan mengkaji pengaruh Na-alginat terhadap pembentukkan partikel grafen sebagai bentuk interaksi elektrostatik antar keduanya. Pencampuran material dilakukan menggunakan metode percampuran kimia. Karakterisasi komposit dilakukan menggunakan spektrofotometer inframerah (FT-IR) untuk mengamati perubahan serapan dan gugus fungsi komposit. Energi disosiasi ikatan (BDE) didapatkan 14 kali lebih besar akibat pengaruh interaksi Na-alginat dalam proses exfoliasi membentuk kompleks komposit. Kajian ini akan sangat berkontribusi dalam mendesain dan sintesis senyawa lapis tipis semikonduktor dari bahan grafit.
\end{abstract}

Kata kunci : Na-alginat, grafit, grafen, eksfoliasi, semikonduktor, BDE

\begin{abstract}
The study of the effect of Na-alginate addition in graphite exfoliation process has been done through synthesis and computational studies using density function theory at B3LYP/6-31G(d) level. This study aims to assess the impact of particles Na-alginate it was reflected from graphene as an electrostatic interaction. The composite characterization was performed using an infrared spectrophotometer to observe changes in absorption and composite functional group. Bond dissociation energy (BDE) was obtained 14 times higher due to the influence of $\mathrm{Na}$-alginate interactions in the exfoliation process to form a complex composite. This study would have a good contribution in design and synthesis of semiconductor thin layer compounds from graphite materials
\end{abstract}

Keywords: Na-alginate, graphite, graphene, exfoliation, semiconductor, BDE

\section{PENDAHULUAN}

Cahaya matahari merupakan sumber energi yang sangat besar dan tidak akan pernah habis, cahaya yang dipancarkan ke bumi dapat dimanfaatkan untuk berbagai macam kebutuhan diantaranya pembangkit listrik dengan sistem sel surya, fotovoltatic [1], DSSC (Dye Sensitized Solar Cell) [2], juga dalam reaksi fotoredoks sebagai pembersihan diri dan anti bakteri $[3,4]$.

Sel surya adalah jenis teknologi penyimpan sekaligus konverter energi cahaya matahari menjadi energi listrik. secara langsung menggunakan prinsip fotovoltaik. Oleh karena itu, teknologi semikonduktor sekarang ini banyak dikembangkan untuk memunculkan inovasi dalam sel surya, salah satunya penggunaan material grafit. Grafit adalah salah satu bentuk alotrop dari bahan dasar karbon yang tersusun dari tumpukan lembaran planar duadimensi (2D), memiliki bentuk seperti sarang lebah dengan panjang ikatan karbon-karbon sebesar 1,42 $\AA$ [5], elektron di dalam grafit berperilaku seperti partikel relativitas tak bermassa dan terdelokalisasi, mempunyai keistimewaan seperti sifat mekanis seperti logam, ringan dan mempunyai sifat yang baik serta dari segi ekonomi bahan dasar grafit buatan tersedia melimpah dan murah [6].

Penelitian terdahulu yang membuktikan sifat semikonduktor pada grafit, diantaranya sebagai semikonduktor sel surya [7], grafit sebagai semikonduktor fotokatalist [8], dan grafit-grafen sebagai material semikonduktor magnet dielektrik [9], dan juga banyak digunakan sebagai elektroda karena sifat konduktornya. Namun, grafit dapat teroksidasi oleh oksigen membentuk $\mathrm{CO}_{2}$ pada temperatur $700{ }^{\circ} \mathrm{C}[10]$.

Pengunaan grafit sebagai material semikonduktor pembangun sel surya, grafit harus dieksfoliasikan terlebih dahulu untuk membentuk grafen. Grafen memiliki struktur lembaran planar, atom karbon dalam setiap lapisnya berbentuk segienam yang terikat secara kovalen.

Alginat yang merupakan molekul polimer alam dari ganggang laut, polimer polianion yang secara alami mampu mengikat kation dalam bentuk kompleks kelat ligan, dimana alginat berposisi 
sebagai ligan, dan kation sebagai atom pusat sehingga dengan kata lain dapat digunakan sebagai adsorben alami. Keberadaan kation $\mathrm{Na}$ dalam $\mathrm{Na}-$ alginat diharapkan dapat digunakan untuk berikatan dengan partikel grafen membentuk lapis tipis.

Mengadaptasi dari sifat grafit dan $\mathrm{Na}$ alginat maka dalam penelitian ini, Na-alginat didesain skema proses pembentukkan grafen menggunakan material Na-alginat menjadi komposit melalui metode percampuran. Diharapkan dapat membentuk komposit yang terdiri dari grafen dengan sifat semikonduktor yang dapat digunakan sebagai material penyusun solar sel. Interaksi grafen yang terbentuk dianalisis dengan pemodelan kimia komputasi untuk mengetahui stabilitas interaksi struktur baik dari ikatan yang terbentuk.

\section{METODE PENELITIAN}

Bahan yang digunakan adalah karbon (grafit) yang dibeli dari Merck.Co., material Naalginat (viskositas $1200 \mathrm{cps}, \mathrm{pH}=7-8$ ) dari Kelco Co, dan aquades Peralatan yang digunakan adalah alat gelas, Spektrofotometer Inframerah (Shimadzu FTIR 8201 PC).

\section{Sintesis komposit grafen/Na-Alginat}

Sebanyak $125 \mathrm{~mL}$ akuades disiapkan didalam gelas beker $250 \mathrm{~mL}$, dilanjutkan dengan memasukkan serbuk Na-alginat sebanyak 0.5 gram kemudian ditambahkan sebanyak 1 gram serbuk grafit. Campuran diaduk selama 24 jam. Setelah itu campuran dikeringkan dalam oven pada suhu $60^{\circ} \mathrm{C}$. Hasil komposit yang terbentuk berupa serbuk kemudian dianalisis dengan spektrofotometer inframerah

\section{Studi Komputasi Menghitung Energi}

Perhitungan komputasi untuk semua model dioptimasi melalui perangkat lunak Gaussian 09W [11], dengan menggunakan metode teori fungsi kerapatan pada level B3LYP/6-31G(d) untuk menghitung energi dan Bond Dissociation Energy (BDE). Tujuan menghitung BDE untuk mengetahui seberapa besar sensitivitas ikatan kompleks yang terbentuk antara molekul grafen/alginat (G/A) dan grafen/Na-alginat (G/N/A), dengan rumus sebagai berikut :

$$
\begin{gathered}
E 1=E(\mathrm{G})+E(\mathrm{~A})-E(G / A) \\
E 2=E(\mathrm{G})+E(\mathrm{~N})+E(\mathrm{~A})-E(\mathrm{G} / \mathrm{N} / \mathrm{A})
\end{gathered}
$$

dimana E1 adalah besar BDE dari kompleks (G/A) yang terbentuk dari molekul grafen, $E(\mathrm{G})$ dan alginat, $E(\mathrm{~A})$. E2 adalah nilai BDE dari kompleks (G/N/A) yang terbentuk dari molekul grafen, $E(\mathrm{G})$, kation $\mathrm{Na} E(\mathrm{~N})$ dan alginat, $E(\mathrm{~A})$.

\section{HASIL PENELITIAN}

Komposit disintesis dengan melarut-kan Na-alginat sebanyak 0,5 gram dilanjutkan dengan penambahan 1 gram powder grafit, tanpa variasi komposisi berat Na-alginat, hal ini dimaksudkan untuk mendapatkan dasar asumsi Na-alginat memiliki kemampuan berinteraksi dengan grafit, serta mengeksfoliasi partikel grafen. Percampuran secara kimia diharapkan lebih memaksimalkan interaksi antar partikel molekul. Interaksi grafen-NaAlginat ditambah gaya akibat proses pengadukan menyebabkan terlepasnya lembaran grafen dari partikel grafit, dan berakibat menurunnya jumlah partikel grafit yang ada. Dan yang terbentuk adalah partikel baru grafen-Na-Alginat, seperti yang diilustrasi-kan dalam Gambar 1.

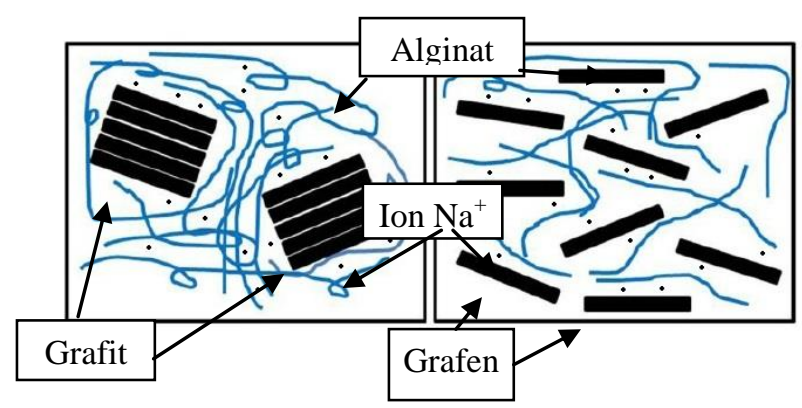

Gambar 1. Ilustrasi grafit yang mengalami pemisahan (separation) dengan sesama partikel grafit(a). Grafit yang mengalami proses eksfoliasi membentuk grafen (b)

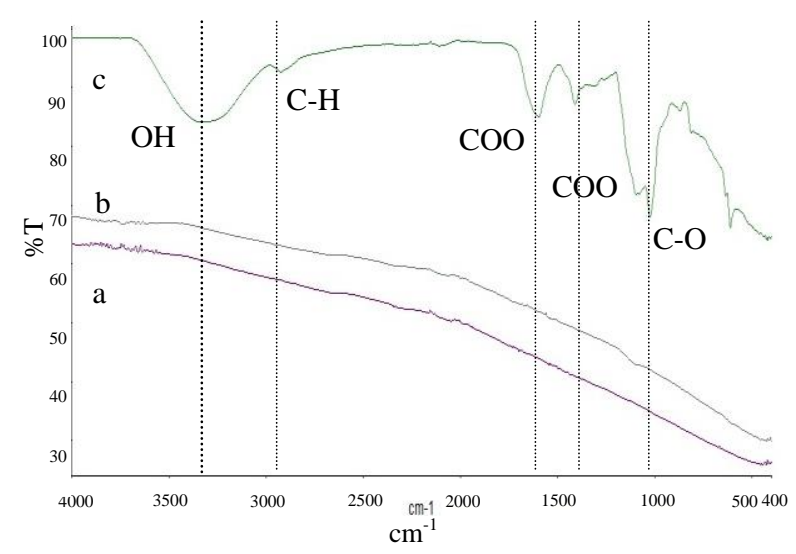

Gambar 2. Spektra inframerah dari karbon grafit (a), komposit grafen/Na-alginat (b), Na-alginat (c)

Spektra grafit Gambar 2a memiliki profil penampilan spektra yang datar namun tetap memiliki serapan inframerah yang besar disetiap rentang bilangan gelombang inframerah, hal ini disebabkan spektra serapan dari grafit yang tidak murni. karena grafit dapat menyerap setiap rentang bilangan gelombang inframerah yang diberikan [12]. Pembentukan grafen dari partikel grafit diidentifikasikan dari penurunan daya serapan 
infrared yang awalnya kuat dan beragam dari gambar (2a) menjadi menurun pada gambar (2b)

Gambar 2c menunjukkan spektra inframerah dari Na-alginat memperlihatkan puncak serapan pada bilangan di wilayah gelombang $3450,40 \mathrm{~cm}^{-1} ; 2920,66 \mathrm{~cm}^{-1} ; 1611,34 \mathrm{~cm}^{-1} ; 1440,23$ $\mathrm{cm}^{-1}$; dan 1043,52 $\mathrm{cm}^{-1}$. Puncak-puncak tersebut menginter-pretasikan ikatan yang terdapat pada struktur Na-alginat di antaranya, uluran vibrasi ikatan O-H pada puncak serapan 3450,40 $\mathrm{cm}^{-1}$, uluran vibrasi C-H pada puncak serapan 2920,66 $\mathrm{cm}^{-1}$, uluran asimetris $\mathrm{COO}^{-}$pada bilangan gelombang $1611,34 \mathrm{~cm}^{-1}$, uluran simetris $\mathrm{COO}^{-}$pada bilangan gelombang $1440,23 \mathrm{~cm}^{-1}$, vibrasi $-\mathrm{C}-\mathrm{O}$ dari kelompok eter pada $1043,52 \mathrm{~cm}^{-1}$ [13].

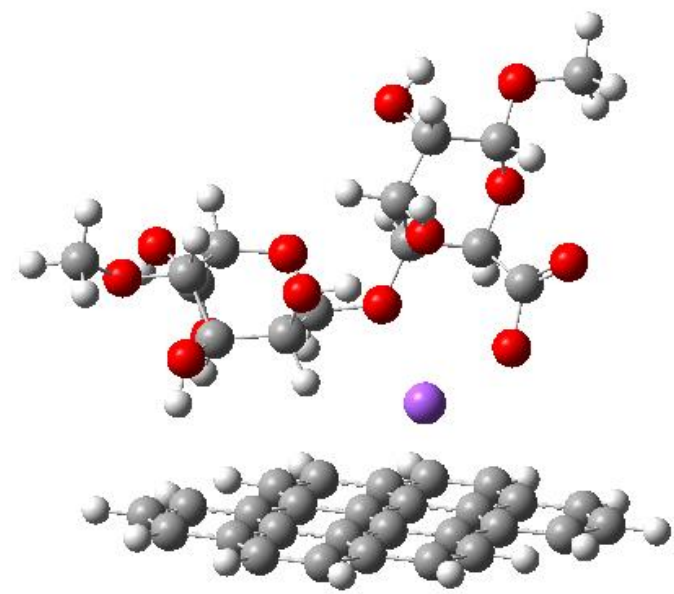

Gambar 3. Interaksi yang terjadi antara grafen-Naalginat

Tabel 1. Perbandingan energi interaksi alginat/grafen

\begin{tabular}{lcc}
\hline Komponen & $\begin{array}{c}\text { Energi molekul } \\
(\mathrm{E} 1)\end{array}$ & $\begin{array}{c}\text { Energi molekul } \\
(\mathrm{E} 2)\end{array}$ \\
& $(\mathrm{Ha})$ & \multicolumn{1}{c}{$(\mathrm{Ha})$} \\
\hline Alginat & -1524.556 & -1524.55 \\
$\mathrm{Na}$ & - & -162.080 \\
Grafen & -1075.534 & -1075.53 \\
Kompleks & -2600.097 & -2762.28 \\
BDE & 0.006387 & 0.11634 \\
\hline
\end{tabular}

*BDE = Bond Dissociation Energy

Dalam komposit 2b spektra serapan $\mathrm{Na}$ alginat tak terlihat, hal ini bisa disebabkan oleh jumlah yang jauh lebih sedikit dibandingkan jumlah grafit yang tereksfoliasi menjadi grafen, sehingga bisa jadi menutupi polimer Na-alginat dengan membentuk kompleks komposit grafen/Na-alginat seperti pada gambar 3.

Proses eksfoliasi partikel grafit membentuk lempengan-lempengan struktur grafen (gambar 3) sebagai akibat interaksi elektrostatik karbon (grafen)-Na-alginat. Alginat dapat berposisi sebagai ligan melalui atom $\mathrm{O}$, maupun gugus karbonil yang dimiliki untuk berinteraksi dengan kation $\mathrm{Na}^{+}$.
Dengan banyaknya atom $\mathrm{O}$ sebagai donor pasangan elektron untuk berinteraksi dengan $\mathrm{Na}^{+}$, maka dapat disimpulkan bahwa interaksi antara Na-alginat juga kuat. Ion $\mathrm{Na}^{+}$juga dapat berinteraksi dengan awan elektron yang dimiliki oleh grafen membentuk interaksi elektrostatik.

Untuk mengetahui besarnya pengaruh Natrium dalam pembentukan kompleks grafen/Naalginat dilakukan melalui perhitungan Bond Dissociation Energy (BDE) yang menyatakan kekuatan ikatan maupun interaksi dari kompleks yang terbentuk, semakin rendah nilai BDE menjelaskan rendahnya molekul komplek untuk terbentuk dari molekul penyusunnya, begitupula sebaliknya

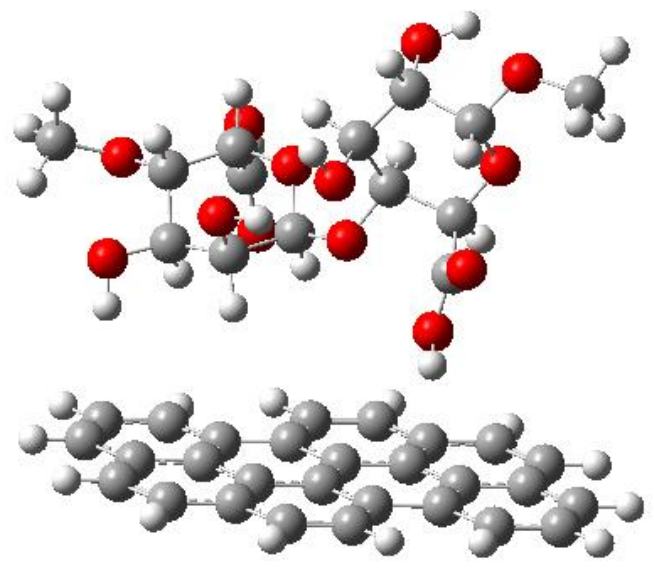

Gambar 4. Interaksi antara alginat dan grafen

Kalkulasi menggunakan metode Density Functional Theory (DFT) dengan basis set 6-31G(d) membandingkan antara bentuk molekul kompleks dari gambar 3 dan gambar 4 didapatkan hasil seperti didalam tabel 1 dimana memperlihatkan nilai BDE meningkat dengan keberadaan ion natrium dari sebesar \pm 14 kali, dari 0,0061387 Ha $(4,023$ $\mathrm{kcal} / \mathrm{mol})$ menjadi sebesar 0,116343 $\mathrm{Ha}(73,296$ $\mathrm{kcal} / \mathrm{mol})$.

Lempengan grafen tidak bisa terlepas dari partikel grafit, dikarenakan interaksi dengan sesama grafen lebih besar dibandingkan interaksi antara alginat dengan grafit, akan tetapi dengan adanya kation natrium $\left(\mathrm{Na}^{+}\right)$interaksi elektrostatik lebih memungkinkan terjadi. Lamanya proses pengadukan membantu interaksi antara $\mathrm{Na}$-alginat dengan grafit dalam proses eksfoliasi grafit dengan adanya interaksi elektrosatik grafen-Na-Alginat.

\section{KESIMPULAN}

Kajian sintesis komposit grafen/Na-alginat telah dilakukan untuk mempelajari pengaruh penambahan $\mathrm{Na}$-alginat dengan percampuran secara kimia dan pengadukan secara mekanik untuk meningkatkan proses pengelupasan material grafit akibat interaksi dengan Na-alginat. Karakterisasi mengguna-kan spektra FT-IR mengindikasikan 
berhasilnya proses eksfoliasi grafit. Peran keberadaan ion $\mathrm{Na}^{+}$sangat penting dalam proses eksfoliasi dalam bentuk interaksi elektrostatik antara Na-alginat dengan partikel grafen, hal ini didukung dengan data BDE hasil komputasi.

\section{UCAPAN TERIMAKASIH}

Kami mengucapkan terimasih atas dukungan dan fasilitas dari Lab. Kimia dan Lab. Komputasi, Prodi Kimia FMIPA UII.

\section{DAFTAR PUSTAKA}

[1] W. Shockley and H. J. Queisser, "Detailed Balance Limit of Efficiency of p-n Junction Solar Cells," J. Appl. Phys., vol. 32, no. 3, p. 510, 1961.

[2] B. O’Regan and M. Grätzel, "A low-cost, high-efficiency solar cell based on dyesensitized colloidal TiO2 films," Nature, vol. 353, no. 6346, pp. 737-740, Oct. 1991.

[3] R. A. Damodar, S.-J. You, and H.-H. Chou, "Study the self cleaning, antibacterial and photocatalytic properties of $\mathrm{TiO} 2$ entrapped PVDF membranes," J. Hazard. Mater., vol. 172, no. 2-3, pp. 1321-1328, Dec. 2009.

[4] W. Sangchay, "The Self-cleaning and Photocatalytic Properties of TiO2 Doped with SnO2 Thin Films Preparation by Sol-gel Method," Energy Procedia, vol. 89, pp. 170 176, Jun. 2016.

[5] J. C. Slonczewski and P. R. Weiss, "Band Structure of Graphite," Phys. Rev., vol. 109, no. 2, pp. 272-279, Jan. 1958.

[6] A. Artadi, Sudaryo, and Aryadi, "Penggunaan grafit batu baterai sebagai alternatif elektroda spektrografi emisi," JFN, vol. 1, no. 2, Nov. 2007.

[7] D. Y. Rahman, M. Rokhmat, E. Yuliza, E. Sustini, and M. Abdullah, "New Design of Potentially Low-cost Solar Cells Using TiO2/Graphite Composite as Photon Absorber," ArXiv150607953 Cond-Mat, Jun. 2015.

[8] Q. Xiang, J. Yu, and M. Jaroniec, "Graphenebased semiconductor photocatalysts," Chem Soc Rev, vol. 41, no. 2, pp. 782-796, 2012.

[9] S. Tongay, "Graphite-graphene semiconductor junctions and magneto-dielectric coupling in Schottky diodes," UNIVERSITY OF FLORIDA, 2010.

[10] D. Hanaor, M. Michelazzi, J. Chenu, C. Leonelli, and C. C. Sorrell, "The effects of firing conditions on the properties of electrophoretically deposited titanium dioxide films on graphite substrates," J. Eur. Ceram. Soc., vol. 31, no. 15, pp. 2877-2885, Dec. 2011.

[11] M. J. Frisch et al., Gaussian 09. Wallingford, CT, USA: Gaussian, Inc., 2009.

[12] R. A. Friedel and G. L. Carlson, "Infrared spectra of ground graphite," J. Phys. Chem., vol. 75, no. 8, pp. 1149-1151, Apr. 1971.

[13] P. L. Nayak and D. Sahoo, "Chitosan-alginate composites blended with cloisite $30 \mathrm{~B}$ as a novel drug delivery system for anticancer drug paclitaxel," Int. J. Plast. Technol., vol. 15, no. 1, pp. 68-81, Jun. 2011. 